\title{
Unravelling the interplay between water and food systems in arid and semi-arid environments: the case of Egypt
}

\author{
Catharien Terwisscha van Scheltinga ${ }^{1}\left[\right.$ - Angel de Miguel Garcia ${ }^{1} \cdot$ Gert-Jan Wilbers $^{1} \cdot$ Hanneke Heesmans ${ }^{1}$. \\ Rutger Dankers $^{1}$. Eric Smaling ${ }^{1}$
}

Received: 23 March 2021 / Accepted: 6 August 2021 / Published online: 8 September 2021

(c) The Author(s) 2021

\begin{abstract}
Food system analysis in arid and semi-arid countries inevitably meets water availability as a major constraining food system driver. Many such countries are net food importers using food subsidy systems, as water resources do not allow national food self-sufficiency. As this leaves countries in a position of dependency on international markets, prices and export bans, it is imperative that every domestic drop of water is used efficiently. In addition, policies can be geared towards 'water footprints', where water use efficiency is not just evaluated at the field level but also at the level of trade and import/export. In this paper, Egyptian food systems are described based on production, distribution and consumption statistics, key drivers and food system outcomes, i.e., health, sustainable land and water use, and inclusiveness. This is done for three coarsely defined Egyptian food systems: traditional, transitional and modern. A water footprint analysis then shows that for four MENA countries, differences occur between national green and blue water volumes, and the volumes imported through imported foods. Egypt has by far the largest blue water volume, but on a per capita basis, other countries are even more water limited. Then for Egypt, the approach is applied to the wheat and poultry sectors. They show opportunities but also limitations when it comes to projected increased water and food needs in the future. An intervention strategy is proposed that looks into strategies to get more out of the food system components production, distribution and consumption. On top of that food subsidy policies as well as smart water footprint application may lead to a set of combined policies that may lead to synergies between the three food system outcomes, paving the way to desirable food system transformation pathways.
\end{abstract}

Keywords Food system $\cdot$ Drivers $\cdot$ Outcomes $\cdot$ Food policy $\cdot$ Water $\cdot$ Water footprint $\cdot$ Sustainability $\cdot$ Egypt

This article belongs to the Topical Collection: Food System Transformations for Healthier Diets, Inclusive Livelihoods and Sustainable Environment

Guest Editors: Romina E Cavatassi, Leslie Lipper, Ruerd Ruben, Eric Smaling, Paul Winters

Catharien Terwisscha van Scheltinga

catharien.terwisscha@wur.nl

Angel de Miguel Garcia

Angel.deMiguelGarcia@wur.nl

Gert-Jan Wilbers

Gert-Jan.Wilbers@wur.nl

Hanneke Heesmans

Hanneke.Heesmans@wur.nl

Rutger Dankers

Rutger.Dankers@wur.nl

Eric Smaling

Eric.Smaling@wur.nl

1 Wageningen University and Research Wageningen Environmental Research Wageningen, Gelderland, Netherlands

\section{Introduction}

The concept of sustainable food systems is gaining prominence in recent years, aiming to "ensure food security and nutrition for all in such a way that the economic, social and environmental bases to generate food security and nutrition of future generations are not compromised" (HLPE, 2017). To feed the current and future population, an approach going beyond the traditional "more-food" perspective is urgently required (Béné et al., 2019).

A food system covers the value chains from production through marketing and processing to consumption, driver groups that cause food systems to transform, and outcome groups that may be satisfactory or give reason for concern. System transformation, deliberate or not, causes the outcomes to change, and synergies and trade-offs may occur (IFAD, 2020). As food system analysis is a rather 
new scientific field (Béné et al., 2019; van Berkum et al., 2018), detailed analyses of national food systems are not yet available.

Water plays an important role in the food system. Water quantity and quality are considered environmental drivers in the food system approach, of particular relevance in waterscarce areas (Arslan et al., 2020). Water is present in the entire food value chain, from food production to processing and consumption. Approximately $7,000 \mathrm{~km}^{3}$ of water is consumed by crops every year (de Fraiture et al., 2007). Irrigated agriculture, accounting for less than $20 \%$ of the total cultivated area in the world, accounts for more than $40 \%$ of the global food production (FAO, 2018). For millions of farmers worldwide, access to water for irrigation is a thin line between poverty and prosperity (Oweis, 2018).

Arid and semi-arid countries are particularly sensitive to increasing population rates in connection with (lack of) economic growth (Charfeddine \& Mrabet, 2017), but also to droughts and climate change. Such countries often import substantial amounts of food as their water availability is insufficient to meet national food demand. When wheat imports became expensive in North Africa due to droughts and fires in Russia, it combined with political instability in what was coined Arab Spring (Soffiantini, 2020). In order to keep import expenditure and urban food prices low, 1- food subsidy systems as safety nets for the needy are inevitable, and 2- smart and well-planned decisions on how to better allocate water for home production becomes of paramount importance (Falkenmark, 2013).

Many people in low and middle-income countries covered by social protection receive assistance in the form of in-kind food. Abdalla and Al-Shawarby (2017) describe the historical development of the food subsidy system in Egypt, starting by saying that food subsidies 'are as old as the nation's pyramids'. The subsidy system evolved from the provision of specific goods in-kind (subsidized at different stages of their production and distribution) in dedicated shops to an open voucher-style subsidy. The contemporary system (tamween) includes the two components of baladi bread (BB) and ration cards (RCs), but continues to face challenges, including shortages of some basic commodities, continued distortions in the market, poor targeting, and lack of adequacy. Subsidies have become embedded as a citizen's right and are therefore strongly linked to the legitimacy of a ruling regime (Abdalla \& Al-Shawarby, 2017; Gutner, 2002). Egypt has experienced several food crises, including a severe one in 2008 when drought and wildfires forced Russia to impose a wheat export ban, leaving major client Egypt to buy elsewhere at sharply rising prices. It clearly shows how sensitive the issue of food self-sufficiency is in a country that is not able to grow all of its own food. Reforms of the system have been subject of study and debate for a long time, trying to make the system more efficient, more targeted to the poor, and comparing price subsidies and vouchers systems with direct cash transfers (Ramadan \& Hosni, 2018; Ramadan \& Thomas, 2011; Talaat, 2018).

One possible way to contribute to a reform of the costly food subsidy system, is by translating food into water. By importing food, one also imports water, allowing to use local water resources for other, higher-value purposes (Wichelns, 2001).

The relationship between water and food can be assessed using different indicators. Their suitability varies according to the purpose and scale of the assessment. Commonly used indicators such as water use efficiency or water productivity are suitable to evaluate on-farm water use, while other broader indicators such as the water footprint or water withdrawal provide a clear overview of the water system when applied at basin or national scales (Fernández et al., 2020). In case of the water footprint, further elaborated below, it also allows to look beyond national borders, by considering virtual water flows embedded in food trade (Mekonnen \& Hoekstra, 2011). This is especially relevant for net food importing countries of water scarce regions.

The objective of this paper is to depict and assess how food systems and water systems interact in a (semi)arid net food-importing country. Amidst several countries in the Mediterranean and North African (MENA) region, Egypt is chosen as a case study for this paper. Three questions are addressed:

1. What are key features of Egyptian food systems, in terms of production - distribution - consumption, in terms of socio-economic and environmental drivers, and in terms of food system outcomes and their interaction (health/ nutrition - sustainability/resilience - inclusivity)

2. What is the water footprint of Egypt, compared to other MENA countries, and what would this mean now and in the future for two important food sectors: wheat and poultry?

3. Which areas of intervention seem promising in order to steer food system outcomes into a direction that guarantees health, sustainability and inclusion?

\section{Materials and methods}

\subsection{Food system framework}

Many frameworks exist that depict the elements of food systems. A generally accepted one is shown in Fig. 1, of the Global Panel on Agriculture and Food Systems for Nutrition (IFPRI, 2016), made up of the production - distribution - consumption connection, the groups of driving forces that impact on the status quo of the former (and vice versa), and the food system outcomes, grouped in diet and health - sustainability and resilience 


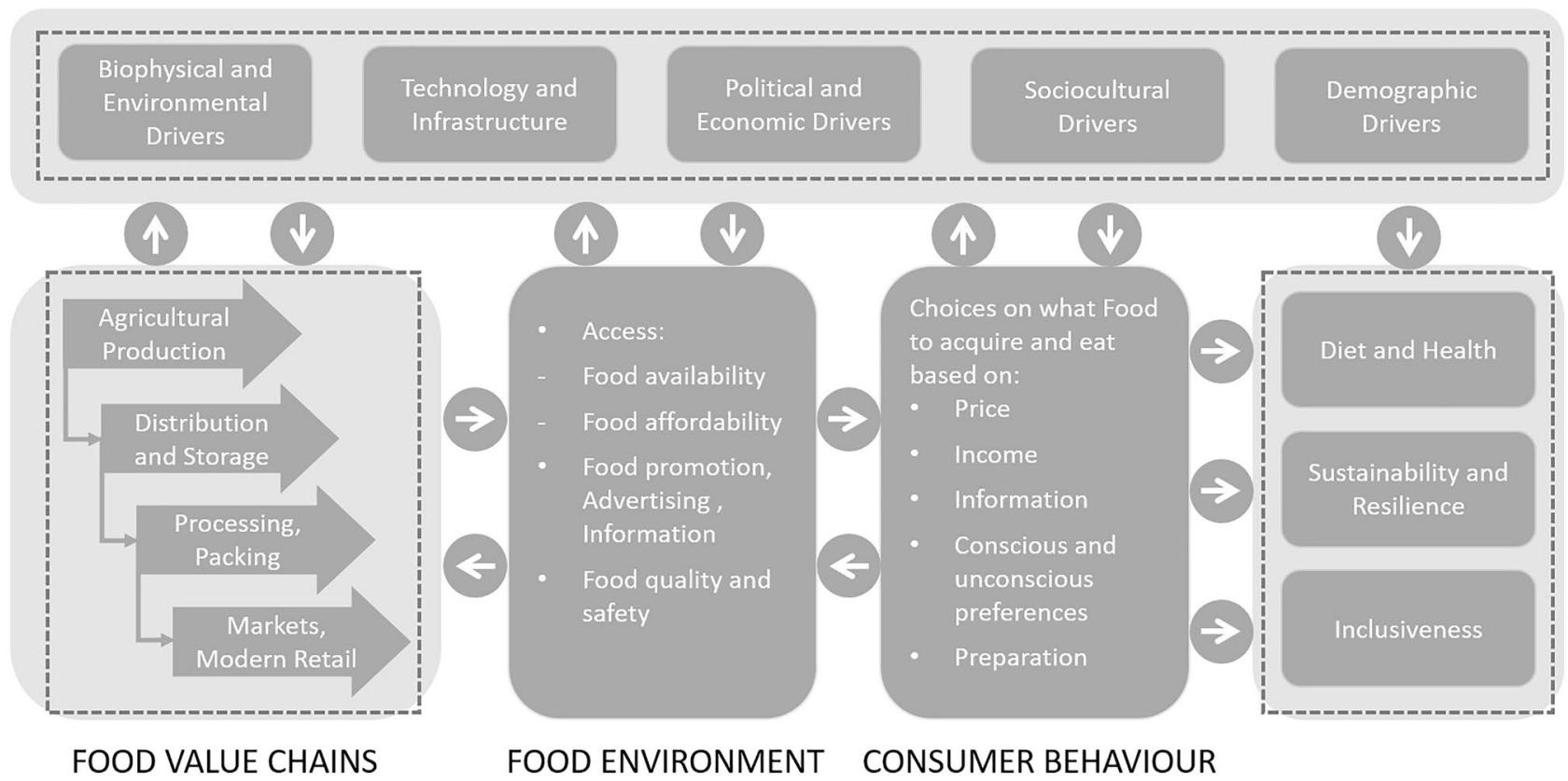

Fig. 1 Food system description according to IFAD (2020) and derived from Global Panel on Agriculture and Food Systems for Nutrition (IFPRI, 2016). The dotted lines highlight where the authors consider there is a particularly relevant connection between food system and water

- inclusiveness. This framework is used to depict the Egyptian food systems with special emphasis on water as a food system driver. Summary statistics from the 1990s to present are used to underpin the case for which most recent globally confirmed data is used covering the 2011-2015 period (FAO, 2021). For future projections, 2030 and 2050 are used as indicative years.

\subsection{The water footprint concept}

The water footprint measures the amount of water consumed to produce each of the goods and services required by humans (Hoekstra et al., 2011). It considers the whole production chain (from production to consumption) and all the direct and indirect flows of water involved, coming from either endogenous or exogenous sources. Unlike water withdrawal based on the use of freshwater resources, the water footprint differentiates between the type and origin of water consumed:

- green water, as the water coming from rainfall, stored in the soil and used directly by plants and crops; and

- blue water, as the water abstracted by humans from rivers and aquifers, amongst others for irrigation.

In order to better understand the potential mismatch between food and water systems in Egypt, the Egyptian food system was analysed following a two-step approach and using a water footprint perspective. The 2011-2015 period was used as a reference for the current situation (named as
2015), since information of agricultural production and trade information was available for this period.

First, the water footprint of food production and consumption of Egypt was calculated and compared with other countries from the MENA region. Water footprint data at country level was extracted from Mekonnen and Hoekstra (2011). This global database contains the most robust statistics on average green and blue water footprint values of specific crops, derived crop products, biofuels, livestock products, and industrial products at national and sub-national level for the period 1996-2005. Data was subsequently updated by the most recent studies available at regional level for the reference year 2015: Wahba et al. (2018) and ElFetyany et al. (2021a) for Egypt; Schyns et al. (2015) for Jordan; Schyns and Hoekstra (2014) for Morocco and Chouchane et al. (2015) for Tunisia.

Second, a more detailed water footprint assessment of two relevant commodities in Egypt, wheat and poultry, was done. While they constitute a relevant part of the Egyptian diet, they also have a wide implication in the water system due to their large current and expected water demand.

The water footprint of the wheat value chain in Egypt was assessed following the methodology of Hoekstra et al. (2011), considering both the national production and the importation. Average data from the trade balance of Egypt for the period 2011-2015 (FAO, 2021; McGill et al., 2015) was used to determine the current volume and origin of wheat, differentiating between domestic production and importation. Wheat consumption at national level 
was derived by subtracting the wheat exportation from the national production and importation. Data from Mekonnen and Hoekstra (2011) of wheat water footprint per country was subsequently used to derive a water footprint value.

The water footprint of the poultry/broiler value chain in Egypt was assessed for the period 2011-2015 (current), and, through production and consumption scenarios, for 2030 and 2050 , by calculating the water footprint of feed. This represents almost $99.7 \%$ of the total water footprint of the sector (Mourad et al., 2019). The current and future chicken meat demand was extracted from FAO $(2017,2021)$. The feed demand of the broiler sector was estimated conservatively, assuming all the chicken is produced nationally and in commercial farming conditions, using a feed conversion factor of 1.7 (feed requirement in tons/ton body weight gain), a canal index of 0.72 (carcass tons/ ton live animal), and considering maize $(60 \%)$ and soybean $(35 \%)$ as the main feed ingredients (Hosny, 2006; Mourad et al., 2019). The ratio between domestic/import feed was estimated using trade balance from FAOSTAT (FAO, 2021) for the period 2013-2017 and the water footprint values of feed were assigned accordingly to their origin from Mekonnen and Hoekstra (2011). Four scenarios based in the current, intermediate and two extreme situations were developed related with the origin of feed: $\mathrm{SC} 1$ assumes the current national/import ratio of feed $(40 \%$ of maize and $100 \%$ of soybean is imported); SC2 assumes $50 \%$ of the feed is produced nationally; SC3 assumes a $100 \%$ national production of feed; $\mathrm{SC} 4$ assumes that feed demand is fully supplied by importation.

\section{Results and discussion}

\subsection{Characterization of Egyptian food systems}

\subsubsection{Production and consumption statistics}

Combined production and consumption statistics related to the food system, compiled in Table 1, show that Egypt's population has been steadily growing by 31 million people between 1997 and 2017, with the expectation of 151 million people in 2050 (FAO, 2021). In addition, Egypt's GDP is growing (from 1,200 USD in 1997 to 3,500 USD in 2017 per capita) due to several economic reforms attracting foreign investments, but this growth is not reaching all inhabitants (Verme et al., 2014).

The share of arable land in Egypt is below 4\% and mainly limited to the Nile Valley and Delta as well as a few oases and some arable land in the desert. Moreover, the arable land area barely increased over the years mainly due to lack of freshwater availability (Index Mundi, 2021a). Except for a small region along the Mediterranean coast, all crops are irrigated by Nile River water (FAO, 2020b), regulated
Table 1 Main water and food characteristics of Egypt (Sources: FAO, 2020a, 2021; Galal, 2002)

\begin{tabular}{llll}
\hline & 1997 & 2007 & 2017 \\
\hline Population (million) & 66 & 79 & 97 \\
GDP per capita (1000 USD) & 1.2 & 1.6 & 3.5 \\
Renewable Water Resources (m ${ }^{3}$ per cap) & 869 & 723 & 589 \\
Area under cultivation (\% of total land) & 3.2 & 3.5 & 3.7 \\
Undernourishment (\% of pop.) & 5.2 & 4.8 & 4.5 \\
Adult obesity (\% of pop. 18+years) & 21 & 25 & 31 \\
Sugar \& Sweetener supply (kg/cap/yr) & 30 & 26 & 27 \\
Vegetables supply (kg/cap/yr) & 175 & 224 & 159 \\
Fruits supply (kg/cap/yr) & 88 & 107 & 103 \\
Cereals supply (kg/cap/yr) & 254 & 244 & 262 \\
Fish supply (kg/cap/yr) & 10 & 18 & 23 \\
Meat supply (kg/cap/yr) & 21 & 28 & 26 \\
\hline
\end{tabular}

upstream by the Aswan reservoir as being the most important fresh water source. From this reservoir, Egypt receives an annual amount of $55.5 \mathrm{~km}^{3}$ of water according to the Sudan-Egypt Waters Agreement of 1959. Even though Egypt has managed to increase agricultural production significantly from 1980 to 2017 (FAO, 2020a), the water availability per person went down from $869 \mathrm{~m}^{3} / \mathrm{capita} / \mathrm{yr}$ in 1997 to $589 \mathrm{~m}^{3} /$ capita/yr in 2017 (Table 1).

From a nutrition perspective, Egypt experiences undernourishment rates between $4.5-5.2 \%$ with a decreasing trend from 1997 onwards. On the other hand, the country has a large share of adult obesity throughout the population with an increasing trend from $24.6 \%$ in 2007 (Table 1) to $31.1 \%$ in 2016 (Statista, 2021a). The latter can be explained as data from food balance sheets show a major shift in the Egyptian food consumption from 1990 to 2017 to an increased amount of calories, sustained rise in (processed) meat and fish consumption, and no reduction in cereal intake (Table 1).

Food security is an issue in Egypt as population numbers are rising whereas there is limited scope to expand arable land. As a result, the country relies on large food imports to meet domestic food demand. Figure 1 shows an overview of trade for some major Egyptian food items.

Egypt is traditionally a net importing country (Fig. 2), where agricultural commodities represent more than $25 \%$ of the total imports (WTO, 2020). Egypt imports about $40 \%$ of its food needs annually and is the largest importer of wheat in the world (FAO, 2021). The import of animal-sourced products has also increased over the last decades due to the change of the dietary habits of the Egyptian population, mainly related with a gradual increase of chicken consumption (Index Mundi, 2021b). On the other hand, Egypt exports high value fruits and vegetables such as citrus, potatoes, onions, grapes, pomegranates, garlic, mangoes, strawberries, beans, guava, cucumbers, peppers, and eggplants. Table 2 
Fig. 2 Net trade of major food items in Egypt (FAO, 2021)

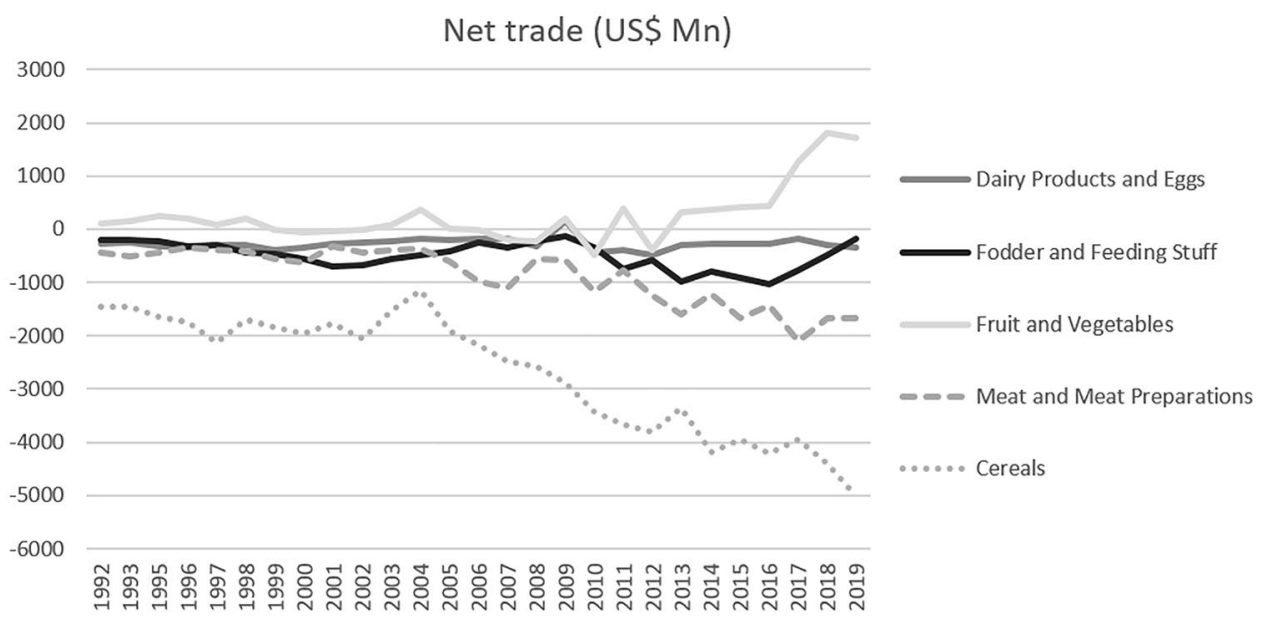

shows that the financial gap between import and export of agricultural goods has grown over time. This table implies that the import - export gap for agricultural commodities in Egypt has widened over the past 30 years, although this was mainly the case between the 2000-2004 and the 2010-2014 time spells.

\subsection{Depicting food systems}

The High-Level Panel of Experts (HLPE, 2017) describes four food system typologies: i) traditional; ii) modern; iii) modern-to-traditional and iv) traditional-to-modern systems covering both food value chains and environment. Based on these typologies and on work by Van den Broek and Boerrighter (2014), three broad types of food systems can be depicted for Egypt:

- Traditional food system;

- Transitional food system;

- Modern or high-tech food system.

\subsubsection{Traditional food system}

This food system is mainly represented by smallholder farmers and comprises $62 \%$ of the population in 2018 (Armanious, 2021). The average annual income is below 38,305 EGP (EUR 2000; USD 2450) in 2015 (CEIC, 2018). Unemployment reached 11.4 percent in 2018, with more than three quarters of the jobless aged 15-29 (IFAD, 2019).
Some $3.2 \%$ of the population in this food system lives under the 1.9 USD poverty line (WB, 2020). Agricultural production is mostly for own and/or family consumption as sizes of land are too small to commercially grow crops (average farm size is between $1-3$ feddan $(0.42-1.26$ ha). As such the producers and consumers are basically the same people. Farmers own their own livestock (cow, buffalo, sheep, goats, chicken) for milk and meat and grow wheat, vegetables and maize for home consumption. Food is not distributed outside the region and usually directly prepared and consumed. There is little trade, and mechanization is rarely used. People in this food system often rely on a second job (e.g. construction sector) to add to their family income.

\subsubsection{Transitional food system}

This food system is made up of farmers with generally higher income (over 38,305 EGP (EUR 2000; 2450 USD/yr) and accounts for around 24\% of the total population in Egypt in 2018 (Armanious, 2021; CEIC, 2018). In transitional food systems, farmers produce food mainly for own consumption but in addition grow cash crops such as vegetables and cotton which are traded on the markets. Farm size is between 3 - 20 feddan (1.26-8.40 ha) and there is moderate to good access to domestic markets through middlemen which allow for food trade. This food system encompasses people from rural areas with larger land size as well as people from cities that purchase domestically produced food items on markets

Table 2 Trade in Egypt (FAO, 2021) in million USD

\begin{tabular}{llllrr}
\hline & $\mathbf{1 9 9 0 - 1 9 9 4}$ & $\mathbf{1 9 9 5 - 1 9 9 9}$ & $\mathbf{2 0 0 0 - 2 0 0 4}$ & $\mathbf{2 0 1 0 - 2 0 1 4}$ & $\mathbf{2 0 1 4 - 2 0 1 9}$ \\
\hline Average agricultural imports per year & 2,642 & 3,583 & 3,249 & 13,943 & 13,053 \\
Average agricultural exports per year & 426 & 531 & 832 & 4,292 & 4,716 \\
Export - Import & $-2,216$ & $-3,052$ & $-2,417$ & $-9,651$ & $-8,337$ \\
\hline
\end{tabular}


or as street food. The latter is represented mostly by unprocessed food items.

\subsubsection{Modern or high-tech food system}

This food system includes people who own farmland larger than 20 feddan ( $8.40 \mathrm{ha}$ ) to produce large volumes of agricultural products, use patented variety crops (citrus fruits, vegetables), have well-organized supply chains and use foreign knowledge by hiring international consultants and experts leading to high income. At the same time, it comprises people who live in large cities (e.g. Cairo) which can afford high quality processed food items in modern supermarkets and restaurants. This food system is characterized by a large dependency on imports. From a production side, imports include agri-chemicals, services and equipment to cultivate food, while for consumers, diets are significantly based on imported (semi)processed food from abroad. Income levels are high, even up to European standards, annually over 51,178 EGP (EUR 2700; USD 3300) and around 13\% of the Egyptian population lives in this food system (CEIC, 2018).

\subsection{Food System Drivers}

Below, a brief account is given how the five driver groups of Fig. 1 work out for Egypt.

\subsubsection{Biophysical and environmental drivers}

Water as the main driver for food systems in Egypt, is also required for other sectors, such as household, industry and recreation (tourism) (Central Agency for Public Mobilization And Statistics, n.d.). However, Egypt is dealing with severe water scarcity as can be observed in the national water balance of Egypt (Omar \& Moussa, 2016) in Table 3.

In total, Egypt requires more water $\left(79.5 \mathrm{~km}^{3} / \mathrm{yr}\right)$ than the available renewable resources, calculated as the total water inflow minus the non-renewable groundwater from the desert $\left(63.6 \mathrm{~km}^{3} / \mathrm{yr}\right)$. ElFetyany et al. (2021a) estimate the total available water resources in 2012-2016 at around 76 billion $\mathrm{m} 3$, and the national water footprint at 107-115 billion m3, suggesting an even larger water resources deficit of $47 \%$.

Table 3 Egyptian water balance (Omar \& Moussa, 2016) in billion cubic kilometers $\left(\mathrm{km}^{3}\right)$

\begin{tabular}{lr}
\hline Nile River & $\mathbf{5 5 . 5}$ \\
\hline Rainfall & 1.6 \\
Non-renewable groundwater from desert & 2.4 \\
Shallow groundwater & 6.5 \\
Total water inflow & 66.0 \\
Water requirements by all sectors & 79.5 \\
\hline
\end{tabular}

Climate change may impact future water availability, in the upstream supply areas as well as in the Nile delta itself. Projections of changes in rainfall range from a $15 \%$ decrease to a $10 \%$ increase by mid-century (Ter Maat \& Wolters, 2016). The combination of increasing sea level rise, saltwater intrusion and progressive groundwater extraction cause the largest reduction in fresh groundwater resources (Mabrouk et al., 2018). Regional climate models predict temperature rises (of $1.6 \pm 0.6{ }^{\circ} \mathrm{C}$ by 2050 , and $2.6 \pm 1.0^{\circ} \mathrm{C}$ in the Nile delta by the end of the century and occurrence of more frequent heat extremes may have direct negative impacts on wheat yields and other crops (Ter Maat \& Wolters, 2016; Ali et al., 2020; Fawaz \& Soliman, 2016; Omar et al., 2021).

\subsubsection{Technology and infrastructure related to water}

Water infrastructure coverage has grown and in 2014, around $91 \%$ of the Egyptian population received water directly into their residence (UNICEF, 2021). Of the 7.3 million people deprived of safe water access, 5.8 million live in rural areas and 1.5 million in urban areas. In addition, 8.4 million people are deprived of access to improved sanitation, mostly in rural areas (UNICEF, 2021).

Egypt is performing well compared to countries in a similar state of development. In summary, the current status of technology and infrastructure is not regarded as a main factor that negatively affects food systems, except for water and sanitation particularly at traditional and transitional food systems.

\subsubsection{Political and economic drivers}

Where Egypt was self-sufficient in almost all basic food commodities in 1960, the slow growth of agricultural yields did not match the rapid rise of population, income, and subsidies prices for food in the 1970s (Metz, 1990). The lack of food self-sufficiency is regarded a risk for societal stability and economic growth which came true during the food crisis of 2008 when high imports in combination with sharp increases in prices of staple food (e.g. wheat) caused civil unrest. The main food items subsidized by Egypt are also the most imported food items; wheat, sugar and cooking oil. The country aims to achieve food self-sufficiency in basic food commodities to reduce dependency on food imports (Ministry of Agriculture \& Land Reclamation of Egypt, 2018). The water resources management plans of Egypt are prioritizing irrigation efficiency and modernization as a response. However, other strategies are required, such as the reduction of food waste, that in some cases such as cereals, could reach a value of $12-14 \%$ of the net available cereals for consumption in the country due to poor storage (ElFetyany et al., 2021b). 


\subsubsection{Socio-cultural drivers}

In all Egyptian food systems, a combination of bread, cereals and legumes are consumed as a main source of calories and proteins. Due to a lower to vast economic growth of $1-7 \%$ / yr since the 1990's (World Bank, 2021) dietary patterns changed. In more urban areas, with modern food systems, the focus shifted to take-away type of meals, with more meat and sugar rich desserts (Hassan-Wassef, 2004). At the same time the dominance of fruits and vegetables in daily consumption decreased. In the traditional and transitional food systems dietary changes are observed due to the food subsidy scheme; street food vendors sell relatively cheap oil rich food items such as fried chicken and other meat products. However, for all food systems, the lack of investment in nutrition-sensitive infrastructure and public services and nutrition specific interventions are also regarded as a main reason for increasing unhealthy food consumption (Ecker et al., 2016).

\subsubsection{Demographic drivers}

Table 1 showed that the population grew from 66 to 97 million people between 1997 and 2017. This growth can partially be explained by increased life expectancy from 40 years in 1950 to over 70 years in 2020 . The female fertility rate is over 3 in 2020, down from 7 in 1955, but still causing mounting pressure on resources (WorldOMeter, 2021). Urbanization remained stable at around $43 \%$ since 2009 (Statista, 2021b). The per capita income rose sharply from 163 USD in 1965 to 3,019 USD in 2019 (in 2021 USD value; source World Bank, 2021), but poverty rates as an indicator for employment show differences between regions, i.e., $15.7 \%$ in metropolitan areas, $11 \%-26 \%$ in other urbanized areas, and 17\%-49\% in rural areas (Ecker et al., 2016). These areas link to modern, transitional and traditional food systems respectively.

\subsection{Food system outcomes}

Food system outcomes for Egypt are described based on the categories identified by the Global Panel on Agriculture and Food Systems for Nutrition (IFPRI, 2016) in Fig. 1.

\subsubsection{Diet and health}

The change of the dietary pattern towards more meat and fish as well as increasing wheat, sugars, and oil/fats consumption has significant effects on the nutritional status of Egyptian people. The prevalent overweight rate is $31 \%$ of all people aged 18 years and older (Statista, 2021a). The changes in diets towards these food items has also been associated with food subsidies related to wheat and oil products
(Asfaw, 2006, 2007). At the same time, Egypt still deals with undernourished people. The national prevalence of underfive stunting is for example 21\% in 2014 (UNICEF, 2020). Both under- and overnutrition (through excess consumption of calories) are widespread throughout the country and visible in all three Egyptian food systems, with rural—urban differences observed in the prevalence of stunting of children under 5 (27\% in urban versus $30 \%$ in rural regions) and overweight more often visible in urban areas (UNFPA, 2010). Insufficient food subsidy schemes, lack of awareness programmes with respect to healthy food and other socio-economic effects are identified as main drivers of this unhealthy situation.

The dietary pattern also has a large influence on the water resources required to domestically produce food as well as on import (virtual water), and vice versa. For example, meatbased diets are linked with a higher water footprint than the vegetable-rich diets, since livestock products generally have a larger water footprint than crop products, both per $\mathrm{kg}$ and per calorie (Hoekstra, 2014). Diets focussed on increased animal-sources food intake require more water than available, demanding high food imports which comes at a high cost.

Obesity and at the same time undernutrition are observed through all layers of the population and thus in all food system. Even though obesity is more present in urban areas (transitional and modern food systems), undernutrition is more frequently observed in rural areas (traditional and transitional food systems).

\subsubsection{Sustainability and resilience}

The overall food system in Egypt is unsustainably using water (see Table 3 and ElFetyany et al. (2021a). The traditional and transitional food systems mainly rely on Nile water which is used for irrigation of agricultural lands either via direct canal irrigation or indirectly through (shallow) groundwater. Although various programmes have been initiated to increase irrigation efficiency, the irrigation practices in these food systems are still mainly based on traditional/ conventional techniques which are inefficient, leading to excess water use by the agricultural production sector (Amer et al., 2017). Moreover, these systems also include cultivation of water intensive crops such as rice, sugar cane or bananas, and deal with highly polluted water as vast loads of untreated waste- and sewage water are discharged on the water system. This is putting additional pressure on the availability of freshwater resources. Water treatment is not widely implemented while availability of desalinated water is not present due to high costs. There is a general lack of understanding and low public awareness in water saving and prevention of water pollution throughout these food systems (Amer et al., 2017). 
The traditional food system is not very resilient toward the impacts of climate change. In general, this food system can be described as a natural food environment where people are dependent on land, water and other resources which are locally available. Water availability and soil salinity are for example two important parameters that decide what food is grown and consumed. Changes in environmental conditions (e.g. water availability and soil quality) due to climate change may have a severe impact, and as mechanization, technology and knowledge on mitigation measures is often lacking, the traditional food system is particularly vulnerable towards climate change.

The transitional food system has more opportunities to address changes through cropping pattern adaptation measures (Omar et al., 2021), purchase of equipment, techniques and additives to better cope with climate change effects. Improving coastal zone management can significantly reduce the vulnerability of the coast to future climate change. Another important adaptation measure is spatial planning. The modern food system is characterized as a system with a high level of control and therefore a higher resilience level towards climate change.

\subsubsection{Inclusiveness}

In Egypt, smallholder farmers play a crucial role in food systems as the suppliers of food but also as main consumers, with around 24 million people (around a quarter of the population) involved in agriculture for their livelihood (FAO, 2020a). In the traditional food system in Egypt, the smallholder farmers are both the producer and main consumer of food with little interaction with the broader market. There is little added value in the agricultural products, which hampers growth in family income as well as the national economy at large. Moreover, due to large population and small amount of arable land due to water scarcity, most farmers own relative small plots of agricultural fields. As a result, many farmers rely on second jobs to add to family income, although not many job opportunities exist in the rural areas. As such, the poverty rate in rural areas is high.

The transitional food system is more dynamic from a market perspective as relationships between producers and markets exist, and prices are negotiated based on personal economic goals. The markets are more complex as they include input providers (e.g. fertilizers, mechanization equipment), shopkeepers, traders and processors, and generate more added value to food and thus economic growth for both young and elderly people. The transitional food system has more access to and involvement of urban areas, in which poverty rates are generally lower compared to rural areas.
The modern food system has the highest level of market dynamics as it provides a large variety of job opportunities as these markets are well-developed and consist of complex value chains including certification of products and making use of high-tech equipment and (international) services to maximize agricultural yields and income. The modern Egyptian food system produces high quality food that meets international standards with respect to food safety and provide a decent income for both farmers as well as for its service providers. It generates jobs at all educational levels (Van den Broek \& Boerrighter, 2014). Moreover, it is also observed that the poverty rate is urban areas (which mainly entail modern food system) is significantly lower compared to rural areas.

\subsection{Integrated analysis of the water and food systems, using the water footprint concept}

\subsubsection{Water footprint of food production and consumption in the MENA region}

Within the MENA countries analyzed, Egypt is the country with by far the highest water footprint both for food production and consumption. As it can be shown in Fig. 3, the water footprint of food production (WFP) is $50.2 \mathrm{~km}^{3} / \mathrm{yr}$ for Egypt (76\% blue water), $1.2 \mathrm{~km}^{3} / \mathrm{yr}$ for Jordan (35\% blue water), $36.8 \mathrm{~km}^{3} / \mathrm{yr}$ for Morocco (19\% blue water) and $18.2 \mathrm{~km}^{3} /$ $\mathrm{yr}$ for Tunisia ( $8 \%$ blue water). This food is produced, in all analyzed countries, consuming a large amount of their freshwater resources, going from the $25 \%$ of the total renewable water resources in case of Morocco, to 30\% for Tunisia, $45 \%$ for Jordan and almost $66 \%$ for Egypt.

From the food consumption perspective, all the analyzed countries present a higher water footprint than the one related with its agricultural production, Egypt being the country with the largest water footprint (Fig. 3). The total water footprint of food consumption (WFC) is $76.2 \mathrm{~km}^{3} /$ yr for Egypt (49\% blue water), $7.3 \mathrm{~km}^{3} / \mathrm{yr}$ for Jordan (5\% blue water), $46.6 \mathrm{~km}^{3} / \mathrm{yr}$ for Morocco ( $10 \%$ blue water) and $22.2 \mathrm{~km}^{3} / \mathrm{yr}$ for Tunisia (6\% blue water). Values reported by ElFetyany et al. (2021a) for agriculture in Egypt for the 2012-2016 period are even higher with a water footprint of food consumption estimated at $95 \mathrm{~km}^{3} / \mathrm{yr}$, but with a very similar green/blue pattern.

The food produced within the MENA countries has a relatively large blue water footprint component compared with the green water-based food imported from more waterabundant regions. This is because irrigation is key to produce food in the MENA region. Figure 3 shows that this is especially true for Egypt, where most agriculture is done under irrigated conditions. Morocco, Jordan and Tunisia all have a considerable green-water footprint too. 
Fig. 3 National and imported green and blue water footprint of agricultural production and consumption in some countries of the MENA region (Egypt, Jordan, Morocco and Tunisia) for the 2011-2015 period in $\mathrm{km}^{3}$ /year; where WFP is the water footprint of food production, including crop and livestock, and WFC is the water footprint of food consumption by the national population

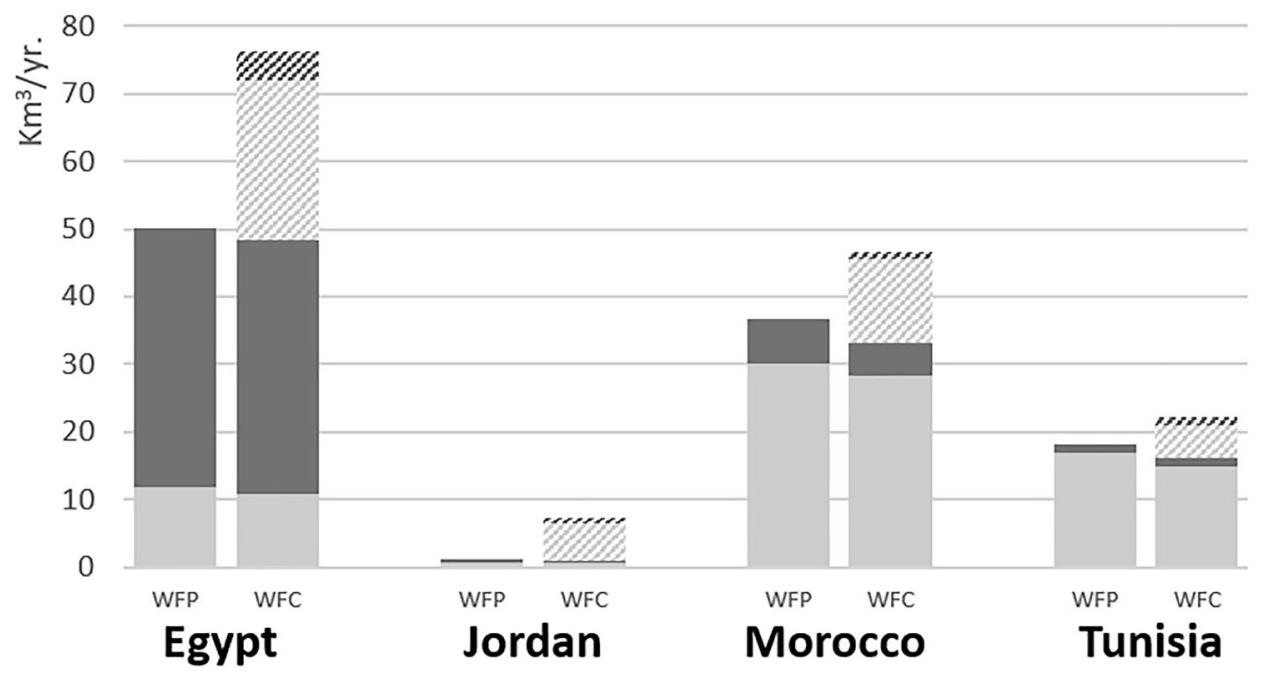

National WFGreen $\square$ National WFBlue Imported WFGreen \& Imported WFBlue
Since the countries are not able to produce all the food demanded by its growing population, they import large quantities of food, thus import water. On average, more than $30 \%$ of the water footprint of food consumption lies outside the country, reflected by the checkered parts of the WFC bars in Fig. 3. More than $80 \%$ of the imported virtual water flow corresponds to green water, usually related with the importation of cereals, feed, or animalsourced products from water abundant regions. By doing this, MENA countries are not only importing the water embedded in agricultural products, but they are also saving precious water resources that could be used for other purposes, such as the production of high added value products for exportation.

The water footprint assessment also provides information related to the water'gap' for food production, now and in the future. The potential water gap for food production is determined by expected increments in population, combined with potential effects in water availability of climate change or infrastructure developments. For instance, Abdelkader et al. (2018) developed a modeling framework to assess the future water gap in Egypt. They modeled several scenarios considering different rates of population growth, increase in water availability by reuse and desalinization, increase in irrigation efficiency and agricultural expansion. They found that while the water availability will remain almost constant, the increment of water demand for municipal use (drinking water, sanitation, industrial use) and especially for food production will increase to almost $100 \mathrm{~km}^{3} / \mathrm{yr}$ by 2050 for Egypt, while the current one is estimated at $76 \mathrm{~km}^{3} / \mathrm{yr}$. This would imply a demand increase of $50 \%$ of water, which is not available.

\subsubsection{Water footprint of the Egyptian Wheat value chain}

Wheat is one of the most essential ingredients in the Egyptians diet, with around $30 \%$ of the average daily calories' intake, estimated in $3160 \mathrm{kcal}$ (FAO, 2021). Wheat represents almost $10 \%$ of the total value of agricultural production and about 20\% of all agricultural imports in Egypt. The price of baladi bread (whose main ingredient is wheat) has been highly subsidized since the early 1970s. A food security and subsidy policy then made wheat more affordable to the population, causing an increment in the consumption from $80 \mathrm{~kg} / \mathrm{capita}$ to the current $146 \mathrm{~kg} / \mathrm{capita}$ per year (McGill et al., 2015). This figure has been fairly stable over the last 20 years and independent of income growth. However, with a growing population, the total national consumption of wheat drastically increased in the last years, going from 2.5 million tons in the early 1960 s to more than 19 million tons in 2018 (Index Mundi, 2021b).

In order to cope with the exponential demand for wheat, the Egyptian government established a national import policy, being by far the largest importer of wheat globally, with a self-sufficient rate of around $45 \%$ (FAO, 2021). There is a heavy involvement of the government in the wheat value chain. The Egyptian government is the major purchaser of domestic wheat, and the General Authority for Supply Commodities alone is the world's biggest wheat purchaser (McGill et al., 2015). Thus, from the 19 million tons consumed yearly in Egypt, almost 9 million are produced locally, either for direct consumption by the farmers (or used as seed and feed) or purchased by the government. The remaining 10 million tons are imported both by the government ( 4.3 million tons) and by the private sector (5.7 million tons). 
Unlike other water abundant regions of the world, the production of wheat in Egypt depends exclusively on irrigation and therefore has a large blue water component. Although the total water required to produce $1 \mathrm{~kg}$ of wheat from Egypt is lower than the one than from the largest world producers, such as China or Russia, in the latter, the blue component is minimal, since wheat is usually grown under rainfed conditions. To produce the 9 million tons of the domestic wheat, Egypt requires almost $10 \mathrm{~km}^{3} / \mathrm{yr}$ of blue water (first bar of Fig. 4). If the imported water (bar 2 in Fig. 4) were not available, Egypt would have needed another amount of green and blue water as depicted in bar 3 of Fig. 4. This $9 \mathrm{~km}^{3} / \mathrm{yr}$ of their blue water can be used in other sectors with a higher added value, such as fruit production for international markets. In line with population growth, the wheat demand in Egypt is also expected to grow from the current 19 million tons to more than 40 million tons in 2050. Extra domestic production will however reach a maximum of 14.5 million tons in the most favorable scenario (Kandagatla \& Almas, 2020). Considering that climate change would increase the wheat water demand by $9 \%$ in the Nile Delta and $18 \%$ in both Middle and Upper Egypt (Ouda et al., 2015), the aspirations of Egypt to increase its self-sufficiency in the near future are met with major challenges.

\subsubsection{Water footprint of the Egyptian broiler value chain}

Due to population growth, economic development and associated dietary changes, the demand for chicken meat as well as other livestock products in Egypt is increasing. As a result, chicken meat demand in Egypt is likely to rise with a stunning $1100 \%$ from the current 1 million in

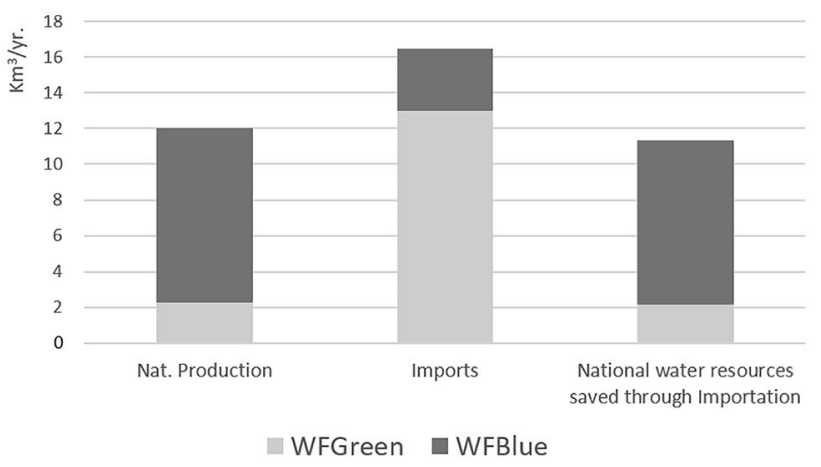

Fig. 4 Green and blue water footprint of wheat consumption in Egypt in $\mathrm{km}^{3} / \mathrm{yr}$ for the period 2011-2015. Nat. Production refers to the water footprint of domestic wheat production; Imports refers to the water footprint of imported wheat and National water resources saved through importation refers to the potential water required to locally produce the imported wheat
2015 to 11 million tons in 2050 (FAO, 2017). Stimulating increasing poultry consumption is positively judged from a nutrition and health perspective if consumed appropriately as it provides a good-quality protein and important sources of micronutrients, and is available at affordable prices (Daghir et al., 2021). Awareness programmes on proper poultry related dishes may however be required as most of the current chicken meat is consumed as fast foods which is not contributing towards a healthy diet. A growth in domestic poultry production will also be beneficial from an employment perspective as it generates jobs in production, processing and logistics (e.g. cool transportation). On the other hand, a large amount of feed is required to cope with the current and expected demand, and this would have implications for Egyptian water resources.

The water footprint of the Egyptian broiler sector for the period $2013-2015$ is estimated at $3.7 \mathrm{~km}^{3} / \mathrm{yr}$ (18\% blue water), of which $80 \%$ is drawn from outside the country, due to the importation of feed (Table 4, Sc1). This figure is slightly different to other MENA countries, where almost $50 \%$ of the feed grains used are produced locally, accounting for $40 \%$ of the total water footprint for animal production (Mourad et al., 2019). If all the feed would have been produced nationally, the total water footprint would remain very similar $\left(3,548 \mathrm{Mm}^{3} / \mathrm{yr}\right)$, but with a large national blue water demand, going from the current $573 \mathrm{Mm}^{3} / \mathrm{yr}$ up to $2,988 \mathrm{Mm}^{3} / \mathrm{yr}$ (Table 4, Sc1 and Sc3). The expected increment in chicken meat demand will have a large increase in the water footprint up to values of 11 $\mathrm{km}^{3} / \mathrm{yr}$ in 2030 and almost $40 \mathrm{~km}^{3} / \mathrm{yr}$ in 2050 for the four scenarios. However, the implication on the national freshwater resources will depend to a large extent on the feed importation strategy. While a strategy mainly based on feed importation (Table 4, Sc1 and Sc4) will minimise the impact on national freshwater resources, a strategy to increase feed domestic supply such as the one modelled for $\mathrm{Sc} 2$ and $\mathrm{Sc} 3$ could increase drastically the national blue water demand from the current $0.5 \mathrm{~km}^{3} / \mathrm{yr}$ up to 16 and 32 $\mathrm{km}^{3} / \mathrm{yr}$ for 2050 respectively (see Table 4).

The importation strategy may have other negative sideeffects, such as soil and water degradation derived from the use of pesticides or even from culling campaigns to control diseases (Gerber et al., 2008).

Hence the strategy on increasing poultry within the food systems depends on the value that governmental and private stakeholders in Egypt attach to the interplay between nutrition, employment and environmental outcomes, i.e., creating synergies between food system outcomes. More research is required to assess and compare the effects of other protein sources (e.g. fish or insects) on water consumption but also on climate change to define the best protein food source or transition pathway from a climate and environment perspective. 
Table 4 Estimation of the annual water footprint of broiler production in Egypt for the years 2015 (2011-2015 period), 2030 and $2050\left(\mathrm{Mm}^{3} / \mathrm{yr}\right)$ for 3 different scenarios $(\mathrm{Sc})$ related with feed origin, where: $\mathrm{Sc} 1$ assumes the current national/ import ratio of feed $(40 \%$ of maize and $100 \%$ of soybean imported); Sc2 assumes an intermediate situation where $50 \%$ of the feed is supplied by importation; Sc3 assumes 100\% national production of feed; Sc4 assumes a $100 \%$ of feed importation

\begin{tabular}{|c|c|c|c|c|c|c|}
\hline & \multirow[b]{2}{*}{ Scenario } & \multicolumn{2}{|c|}{ National Water Footprint } & \multicolumn{2}{|c|}{ Import Water Footprint } & \multirow[b]{2}{*}{$\begin{array}{l}\text { Total Water } \\
\text { Footprint }\end{array}$} \\
\hline & & $\begin{array}{l}\text { National } \\
\text { WFGreen }\end{array}$ & National WFBlue & $\begin{array}{l}\text { Imported } \\
\text { WFGreen }\end{array}$ & $\begin{array}{l}\text { Imported } \\
\text { WFBlue }\end{array}$ & \\
\hline \multirow[t]{4}{*}{-2015} & $S c 1$ & 77 & 573 & 3,012 & 120 & 3,782 \\
\hline & $S c 2$ & 280 & 1,494 & 1,763 & 81 & 3,618 \\
\hline & Sc3 & 560 & 2,988 & - & - & 3,548 \\
\hline & Sc4 & - & - & 3,525 & 163 & 3,688 \\
\hline \multirow[t]{4}{*}{2030} & $S c 1$ & 238 & 1,776 & 9,342 & 374 & 11,729 \\
\hline & $S c 2$ & 869 & 4,633 & 5,467 & 253 & 11,221 \\
\hline & $S c 3$ & 1,738 & 9,266 & - & - & 11,004 \\
\hline & Sc4 & - & - & 10,934 & 505 & 11,439 \\
\hline \multirow[t]{4}{*}{2050} & $S c 1$ & 828 & 6,181 & 32,513 & 1,300 & 40,823 \\
\hline & $S c 2$ & 3,025 & 16,124 & 19,027 & 879 & 39,055 \\
\hline & $S c 3$ & 6,050 & 32,248 & - & - & 38,297 \\
\hline & Sc4 & - & - & 38,054 & 1,758 & 39,812 \\
\hline
\end{tabular}

\section{Potential intervention areas}

Considering Egypt's multiple food systems and their outcomes, water is regarded as the most critical factor to ensure a high level of food self-sufficiency. Water availability and management affects the food systems as it is related to the magnitude of food imports and food subsidies. These in turn determine food system outcomes healthy diets, nutrition and inclusiveness. It could be argued that the Egyptian food subsidy system is mainly caused by water scarcity. In reverse, if sufficient water and thus arable land would be available, the need for subsidizing basic food commodities would not be required as supply would be sufficient to feed the population. As such, improving food system outcomes would entail interventions that have a water perspective.
The analysis of the water footprint of Egypt reveals that most of the freshwater resources from the country are already allocated to feed the nation. Using the water footprint concept as a complementary tool to determine the national food-based dietary need, water scarce countries could reduce their internal blue water consumption while meeting the nutrition requirements (Mirzaie-Nodoushan et al., 2020). For Egypt, a set of 5 potential intervention areas can be listed, that target one or more food system outcomes (Table 5). Adding a water footprint scenario to the other four may help create full synergy between health, environment and inclusiveness, bringing more money in pockets, offering subsidized food at lower spoilage rates to those who need it most while moving to healthier diets, and using water in the most optimal way at the field as well as at the trade level. This would need to be taken up as a full package to reach the target of positive food system transformation.

Table 5 Five areas of intervention that may (when executed in combination) end up addressing all three food system outcomes (health, environment, inclusiveness)

\begin{tabular}{|c|c|c|c|}
\hline $\begin{array}{l}\text { Intervention } \\
\text { area }\end{array}$ & Intervention & Effect & $\begin{array}{l}\text { Food System } \\
\text { Outcome } \\
\text { targeted }\end{array}$ \\
\hline Production & $\begin{array}{l}\text { Improving water / irrigation use and management for } \\
\text { higher production and productivity of high-value } \\
\text { agricultural produce }\end{array}$ & $\begin{array}{l}\text { Agricultural technology aims at getting the most }(\mathrm{kg}, \$ \text {, } \\
\text { equity) out of every drop of water }\end{array}$ & E, I \\
\hline Distribution & $\begin{array}{l}\text { Reducing food loss and waste, while in the process } \\
\text { also saving water from being lost }\end{array}$ & $\begin{array}{l}\text { Policies on lowering losses and waste and better storage } \\
\text { of stocks reduces import burden }\end{array}$ & $\mathrm{H}, \mathrm{E}$ \\
\hline Consumption & $\begin{array}{l}\text { Nudging and pricing towards healthy foods to fight } \\
\text { malnutrition and obesity; increasing visibility of } \\
\text { water use difference between income groups }\end{array}$ & $\begin{array}{l}\text { Consumption patterns move towards a healthier and } \\
\text { more productive population at smaller differences } \\
\text { between rich and poor }\end{array}$ & $\mathrm{H}$ \\
\hline Food subsidy & $\begin{array}{l}\text { Reforming food subsidy system to become more effi- } \\
\text { cient and targeted to the needy (pricing vs rationing } \\
\text { vs cash transfers) }\end{array}$ & $\begin{array}{l}\text { Imports become more efficient and local processing is } \\
\text { stimulated, saving forex, while reaching those who } \\
\text { need it most }\end{array}$ & $\mathrm{H}, \mathrm{I}$ \\
\hline $\begin{array}{l}\text { Water foot- } \\
\text { print }\end{array}$ & $\begin{array}{l}\text { Focus home production/export on high-value and } \\
\text { water-efficient commodities } \\
\text { Focus import on water-consuming commodities }\end{array}$ & $\begin{array}{l}\text { Agricultural policies are based on markets and prices, } \\
\text { but also on (green and blue) water use efficiency at the } \\
\text { field level but also at the trade level }\end{array}$ & H, E, I \\
\hline
\end{tabular}




\subsection{Production}

According to the Agricultural Development Strategy towards 2030 (Ministry of Agriculture and Land Reclamation, 2014), the goal of Egypt is to increase self-sufficiency in wheat from the current $45-50 \%$ to $81 \%$. To do that, the government aims to increase crop yields, making more efficient use of water (more crop per drop) and increasing the area under irrigation from the current 3.3 Mha to 7.7 Mha in 2035 by making more land and non-conventional water resources available.

The use of modern irrigation techniques, such as the cultivation of wheat on raised beds, irrigating wheat with sprinklers or intercropping with other crops such as tomato, cotton or sugar beet could increase yields, reducing the water footprint per ton of product and potentially reducing the wheat production-consumption gap by more than $20 \%$ (Ouda \& Zohry, 2017). The general adoption of raised-bed wheat production in Egypt could lead into a 25\% increase in productivity due to higher yields, $50 \%$ lower seed costs, a $25 \%$ reduction in water use, and lower labor costs (Alwang et al., 2018). However, according to the model developed by Asseng et al. (2018), the ongoing 2030 strategy will not be enough to achieve the aimed self-sufficiency. This would be due to the combined effects of growing demand with higher water requirement and lower yields due to climate change. Moreover, the water required for leaching of salt could increase the water consumption of wheat from the current $10 \mathrm{~km}^{3} / \mathrm{yr}$ to up to $20-29 \mathrm{~km}^{3} / \mathrm{yr}$ in the coming years. Also, implementation of modern irrigation technologies and practices for traditional food systems may be difficult due to required investment costs. As such, it is required to make use of existing technologies available on the market in combination with awareness raising campaigns to stimulate farmers applying (more) modern equipment and tools. In contrast, the farmers in the modern food systems have more humanand financial resources to implement water-efficient irrigation technologies and measures.

\subsection{Distribution}

Food waste reduction should be considered as a key strategy in the food challenge. Food loss and waste is substantial. Holt-Giménez et al. (2012) hold the alarmistic view that 30 to $40 \%$ of food is wasted in developing and developed countries together. FAO (2019) who devoted their State of Food and Agriculture 2019 to food loss and waste come up with $14 \%$ as a figure, but this excludes retail and beyond. In developing countries, the waste befalls on-farm and during the transport and processing, mainly due to unsuitable storage and the absence of efficient food-chains (Godfray et al., 2010). The food waste occurring in values chains is particularly an issue in the transitional and modern food system as these include transportation and processing of food. The traditional food system mostly produces food for selfconsumption where food waste is often used as animal feed.

The Egyptian government operates all large-scale inland storage of wheat, by using a system of traditional flat storage called shona. This system is rather inefficient, causing significant qualitative and quantitative losses from exposure to weather and pests. The losses at the shona are estimated to be in the range of 10-20\%, while the silos technology, mainly used by the private sector, has a loss lower than $2 \%$ (McGill et al., 2015). According to ElFetyany et al. (2021b), the average water losses due to wheat wastage in Egypt is around $6 \mathrm{~km}^{3} / \mathrm{yr}$. The food and water savings from reduced losses by investing in modern storage facilities would compensate several times for the additional cost, with an estimate cost of $0.006 \mathrm{USD} / \mathrm{m}^{3}$. However, the available loss-reducing techniques do not always offer economically attractive returns to farmers, as it was elucidated by Anriquez et al. (2021) for small-scale tomato producers in Egypt. It takes structural reforms to change the strategies of farmers, wholesalers and retailers in this respect.

\subsection{Consumption}

The expected change in dietary patterns due to economic growth and urbanization could increase the consumption of more water-intensive products. The per capita urban water footprint in Egypt is roughly 20\% higher than in the rural areas, mainly due to the higher consumption of animalsourced and processed foods (Wahba et al., 2018). Diets with a small 'meat share' show much smaller water footprints than those where animal-sourced foods are common (Vanham et al., 2018). However, as the water footprint analysis of the chicken meat value chain showed, the domestic blue water footprint is linked mainly to the origin of the feed, and not to the breeding location. Although it is difficult to establish a clear and significant relationship between healthy diets and water, a study in Hungary showed that the 'balanced, sustainable' diet did the best job in both reducing green and blue water footprint, as well as improving dietary quality, compared to the baseline (Tompa et al., 2020). Wealth also matters. A recent study on differences in internal water footprint between Egyptian income and lifestyle groups revealed that the richest households consume 5 times more water in edible products than the poorest, and even around 25 times more in textile and recreation (Wahba, 2021).

By assessing the effects of dietary habits and income level on reducing the national water consumption, a country can design diets with lower water related implications, while still meeting nutrition requirements (Mirzaie-Nodoushan et al., 2020). The water footprint should also be considered as a driver, when national dietary guidelines are developed, in order to boost the consumption of less water intensive food 
products among the population. In doing this, not only the nutritional water productivity should be taken into consideration, but also where the water originates from. The consumption of food items with a large water footprint (dairy products, meat) are particularly associated with the modern food system. The intervention focus should therefore be there.

\subsection{Food subsidies}

The Egyptian government, through the tamween subsidy of baladi bread (Abdalla \& Al-Shawarby, 2017), has an important role at every level of the wheat value chain. The direct and indirect subsidy scheme is linking to wheat production, procurement, flour milling and bakery production. For example, the price offered by the government to national producers is usually set above the world market price in order to encourage domestic production, reduce imports, and improve the balance of payments (Coelli, 2010). However, this causes a high rate of leakage in the system as economic incentives were misaligned, forcing the government to procure more wheat than would have been demanded even at the subsidized price (Kassim et al., 2018). Some measures were already undertaken to by the Egyptian government to shift food subsidies towards the end of the supply chain in order to reduce inefficiencies. By turning bakeries and groceries into market competitors, they have an incentive to improve their efficiency and effectiveness, reducing the leakage of flour to the black market (Abdalla \& Al-Shawarby, 2017). Reform of the food subsidy system has been an ongoing issue, but since it is so politically sensitive, it is not easy to turn scientific output into policies. What can be stated though is that optimization is in the domain of comparing between subsidized prices, rationing and voucher systems, and direct cash transfers to those who need it most. The issue applies to all Egyptian food systems.

\subsection{Water footprint}

Considering that Egypt most likely may not achieve its selfsufficiency aspirations for wheat by 2030 (Asseng et al., 2018), the country would keep relying on food imports. As many other countries from the MENA region, there is a big potential to adopt or further develop water-intelligent food trade. By doing this, water scarce countries are saving a large amount of their freshwater resources via virtual water importation, but also producing a net global reduction in blue water (Gilmont, 2015). According to ElFetyany et al. (2021a) not linking water policy decisions with trade priorities and water security is negatively affecting the efficient water use in Egypt. However, a policy mainly based in grain importation makes the countries vulnerable to international market fluctuations and therefore trade policy should also be considered in the national water planning. For instance, Egypt consumes around $8.4 \mathrm{Km}^{3}$ of freshwater in products for exportation (modern food system) which accounts for $12 \%$ of Egypt total water resources, mainly related to vegetables and fruits, but also to other (relatively) cheap and water intensive products such as paddy rice or forages (Wahba et al., 2018). Smarter decisions on water allocations are needed, supporting farmers making the transition to optimal cropping patterns at the governate level, looking to maximize the economic value of the irrigation water, while keeping a safety degree of self-sufficiency.

\section{Conclusions}

This paper analyzes how Egyptian food systems and water systems are intertwined. Using a food systems approach and linking that to the water system using a water footprint concept, a pathway has been added to assist in helping Egypt's food systems to be transformed to be more healthy, sustainable and profitable in future.

The food system components (production, distribution, consumption) all have characteristics where improvements are possible, e.g., in adopting improved technologies, in reducing waste, and in pushing towards more healthy diets and smaller differences in water use between income groups. A set of food system drivers is discussed, but two stand out for Egyptian food and agriculture: water availability and food subsidies. The two meet each other when looking at water not just at the field scale level, but also at the level of trade, import and export. Water footprint realities can then help in guiding food policies in the country. The same holds for the other MENA countries discussed, although they do not depend that much on blue water as Egypt does. The wheat and poultry cases discussed in this paper show which way to go in order to reach the volumes required in the future as well as the challenges ahead.

In the context of population growth, the aspiration of Egypt to become a more self-sufficient country in the future, by expanding agricultural lands or by increasing water efficiency, will be challenged by the fact that water availability is difficult to increase in the future. Smart water allocation decisions are required to decide if the water resources available are used to produce high added-value crops for exportation, or whether they are allocated for the domestic production of some of the basic food basket items (i.e. cereals and livestock).

Further research on the transition pathways combining food and water systems will be essential for decision makers in Egypt, when considering the future of the food systems. The food crisis in 2008 when Russia banned exports, and the concerns about the new dam in Ethiopia that may 
influence water volumes in the Nile clearly show how delicate food and water are in this currently over 100 million people country.

Acknowledgements This article has been based on the initial work for a background chapter of the Rural Development Report 2021 on Food Systems. The authors gracefully acknowledge support of KB35-008008 and WUR for the completion of this work.

\section{Declarations}

Conflict of interest The authors declared that they have no conflict of interest.

Open Access This article is licensed under a Creative Commons Attribution 4.0 International License, which permits use, sharing, adaptation, distribution and reproduction in any medium or format, as long as you give appropriate credit to the original author(s) and the source, provide a link to the Creative Commons licence, and indicate if changes were made. The images or other third party material in this article are included in the article's Creative Commons licence, unless indicated otherwise in a credit line to the material. If material is not included in the article's Creative Commons licence and your intended use is not permitted by statutory regulation or exceeds the permitted use, you will need to obtain permission directly from the copyright holder. To view a copy of this licence, visit http://creativecommons.org/licenses/by/4.0/.

\section{References}

Abdalla, M., \& Al-Shawarby, S. (2017). The Tamween food subsidy system in Egypt: Evolution and recent implementation reforms. In: Alderman, H., Gentilini, U., \& Yemtsov, R. (Eds.), The 1.5 Billion People Question: Food, Vouchers, or Cash Transfers? (pp. 107-150). World Bank. https://doi.org/10.1596/978-1-4648-10879_ch3

Abdelkader, A., Elshorbagy, A., Tuninetti, M., Laio, F., Ridolfi, L., Fahmy, H., \& Hoekstra, A. Y. (2018). National water, food, and trade modeling framework: The case of Egypt. Science of the Total Environment, 639, 485-496. https://doi.org/10.1016/j.scitotenv. 2018.05.197

Ali, M. G. M., Ibrahim, M. M., El Baroudy, A., Fullen, M., Omar, E. S. H., Ding, Z., \& Kheir, A. M. S. (2020). Climate change impact and adaptation on wheat yield, water use and water use efficiency at North Nile Delta. Frontiers of Earth Science, 14, 1-15. https:// doi.org/10.1007/s11707-019-0806-4

Alwang, J., Sabry, S., Shideed, K., Swelam, A., \& Halila, H. (2018). Economic and food security benefits associated with raised-bed wheat production in Egypt. Food Security, 10(3), 589-601. https:// doi.org/10.1007/s12571-018-0794-3

Amer, M. H., El Hafez, S. A. A., \& El Ghany, M. B. A. (Eds.) (2017). Water saving in irrigated agriculture in Egypt, case studies and lessons learned. LAMBERT Academic Publishing.

Anriquez, G., Foster, W., Ortega, J., \& Rocha, J. S. (2021). In search of economically significant food losses: Evidence from Tunisia and Egypt. Food Policy, 98, 101912. https://doi.org/10.1016/j.foodpol. 2020.101912

Arslan, A., Van Berkum, S., Cavatassi, R. E., Nucci, D., Ruben, R., Smaling, E., Stefanelli, T., de Steenhuijsen Piters, B., Reyes, S., \& Winters, P. (2020). IFAD RDR 2021 - Framework for the Analysis and Assessment of Food Systems Transformations. Retrieved July 2, 2021, from https://www.wur.nl/en/show/ IFAD-framework-food-system-transformations.htm
Armanious, D. M. (2021). Accelerating global actions for a world without poverty: Egypt Experiences. Retrieved July 2, 2021 from https://www.un.org/development/desa/dspd/wp-content/ uploads/sites/22/2021/02/Final-World-without-poverty-Egypt_ 31-january-2021.pdf

Asfaw, A. (2006). The role of food price policy in determining the prevalence of obesity: Evidence from Egypt. Review of Agricultural Economics, 28(3), 305-312. https://doi.org/10.1111/j. 1467-9353.2006.00291.x

Asfaw, A. (2007). Do Government Food Price Policies Affect the Prevalence of Obesity? Empirical Evidence from Egypt. World Development, 35(4), 687-701. https://doi.org/10.1016/j.worlddev. 2006.05.005

Asseng, S., Kheir, A. M., Kassie, B. T., Hoogenboom, G., Abdelaal, A. I., Haman, D. Z., \& Ruane, A. C. (2018). Can Egypt become self-sufficient in wheat? Environmental Research Letters, 13(9), 094012. https://doi.org/10.1088/1748-9326/aada50

Béné, C., Prager, S. D., Achicanoy, H., Alvarez Toro, P., Lamotte, L., Bonilla Cedrez, C., \& Mapes, B. R. (2019). Understanding food systems drivers: A critical review of the literature. Global Food Security, 23, 149-159. https://doi.org/10.1016/j.gfs.2019. 04.009

CAPMAS. (n.d). Wheat production. Retrieved July 2, 2021, from www. capmas.gov.eg/Pages/IndicatorsPage.aspx?page_id=6151\&ind_ $\mathrm{id}=2361$

CEIC. (2018). Egypt Average Household Income: Value. 2005-2018. Retrieved July 2, 2021 from https://www.ceicdata.com/en/egypt/ average-household-income/average-household-income-value

Charfeddine, L., \& Mrabet, Z. (2017). The impact of economic development and social-political factors on ecological footprint: A panel data analysis for 15 MENA countries. Renewable and Sustainable Energy Reviews, 76, 138-154. https://doi.org/10.1016/j. rser.2017.03.031

Chouchane, H., Hoekstra, A. Y., Krol, M. S., \& Mekonnen, M. M. (2015). The water footprint of Tunisia from an economic perspective. Ecological Indicators, 52, 311-319. https://doi.org/10. 1016/j.ecolind.2014.12.015

Coelli, T. (2010). The Cost Efficiency in the Production and Distribution of Subsidised Bread in Egypt. The World Bank.

Daghir, N., Diab-El-Harake, M., \& Kharroubi, S. (2021). Poultry production and its effects on food security in the Middle Eastern and North African region. Journal of Applied Poultry Research, 30(1), 100110. https://doi.org/10.1016/j.japr.2020.10.009

de Fraiture, C., Wichelns, D., Rockstrom, J., Kemp-Benedict, E., Eriyagama, N., Gordon, L. J., Hanjra, M. A., Hoogeveen, J., Huber-Lee, \& Karlberg, L. (2007). Looking ahead to 2050: scenarios of alternative investment approaches. In Molden, D. (Ed.), Water for food, water for life: a Comprehensive Assessment of Water Management in Agriculture (pp. 91-145). Earthscan; International Water Management Institute. https://doi.org/ 10.22004/ag.econ.157926

Ecker, O., Al-Riffai, P., Breisinger, C., \& El-Batrawy, R. (2016). Nutrition and economic development: Exploring Egypt's exceptionalism and the role of food subsidies. Intl Food Policy Res Inst. https://doi.org/10.2499/9780896292383

Falkenmark, M. (2013). Growing water scarcity in agriculture: Future challenge to global water security. Philosophical Transactions of the Royal Society A: Mathematical, Physical and Engineering Sciences, 371(2002), 20120410. https://doi.org/10.1098/rsta.2012.0410

FAO. (2017). Africa Sustainable Livestock 2050 - Country Brief Egypt. Retrieved July 2, 2021, from http://www.fao.org/3/ i7312e/i7312e.pdf

FAO. (2018). The future of food and agriculture-Alternative pathways to 2050. Food and Agriculture Organization of the United Nations. 
FAO. (2019). The state of food and agriculture 2019. Food and Agriculture Organization of the United Nations.

FAO. (2020a). AQUASTAT - FAO's Global Information System on Water and Agriculture. Food and Agriculture Organization of the United Nations (FAO). Retrieved March 31, 2020, from http://www.fao.org/aquastat/en/

FAO. (2020b). FAO in Egypt. Food and Agriculture Organization of the United Nations (FAO). Retrieved July 5, 2021, from http:// www.fao.org/egypt/our-office/egypt-at-a-glance/en/

FAO. (2021). FAOSTAT Food and agriculture data. Food and Agriculture Organization of the United Nations (FAO). Retrieved May 25, 2021, from http://faostat.fao.org/static/syb/syb_59.pdf.

Fawaz, M. M., \& Soliman, S. A. (2016). The potential scenarios of the impacts of climate change on Egyptian resources and agricultural plant production. Open Journal of Applied Sciences, 6(4), 270-286. https://doi.org/10.4236/ojapps.2016.64027

Fernández, J. E., Alcon, F., Diaz-Espejo, A., Hernandez-Santana, V., \& Cuevas, M. V. (2020). Water use indicators and economic analysis for on-farm irrigation decision: A case study of a super high density olive tree orchard. Agricultural Water Management, 237, 106074. https://doi.org/10.1016/j.agwat. 2020.106074

ElFetyany, M., Farag, H., \& Abd El Ghany, S. H. (2021a). Assessment of national water footprint versus water availability-Case study for Egypt. Alexandria Engineering Journal, 60(4), 3577-3585. https://doi.org/10.1016/j.aej.2020.12.038

ElFetyany, M., Kamal, R., Helmy, M., \& Nasr, M. L. (2021b). Study the Effect of Food Waste on Egypt Water Resources - wheat case study. Ain Shams Engineering Journal. In press. https://doi.org/ 10.1016/j.asej.2020.10.024

Galal, O. M. (2002). The nutrition transition in Egypt: Obesity, undernutrition and the food consumption context. Public Health Nutrition, 5(1A), 141-148. https://doi.org/10.1079/PHN2001286

Gerber, P., Opio, C., \& Steinfeld, H. (2008). Poultry production and the environment-a review. In O. Thieme \& D. Pilling (Eds.), Poultry in the 21st Century: avian influenza and beyond. Proceedings of the International Poultry Conference, held 5-7 November 2007, Bangkok, Thailand (extended electronic version, pp. 379-405). FAO Animal Production and Health Proceedings, No. 9.

Gilmont, M. (2015). Water resource decoupling in the MENA through food trade as a mechanism for circumventing national water scarcity. Food Security, 7(6), 1113-1131. https://doi.org/10.1007/ s12571-015-0513-2

Godfray, H. C. J., Beddington, J. R., Crute, I. R., Haddad, L., Lawrence, D., Muir, J. F., Pretty, J., Robinson, S., Thomas, S. M., \& Toulmin, C. (2010). Food security: The challenge of feeding 9 billion. Science, 327(5967), 812-818. https://doi.org/10.1126/science.1185383

Gutner, T. (2002). The political economy of food subsidy reform: The case of Egypt. Food Policy, 27(5-6), 455-476. https://doi.org/10. 1016/S0306-9192(02)00049-0

Hassan-Wassef, H. (2004). Food habits of the Egyptians: Newly emerging trends. La Revue De Santé De La Méditerranée Orientale, 10(6), 898-915.

HLPE. (2017). Nutrition and food systems. A report by the High Level Panel of Experts on Food Security and Nutrition of the Committee on World Food Security. Committee on World Food Security.

Hoekstra, A. Y., Chapagain, A. K., Mekonnen, M. M., \& Aldaya, M. M. (2011). The water footprint assessment manual: Setting the global standard. Routledge.

Hoekstra, A. Y. (2014). Sustainable, efficient, and equitable water use: The three pillars under wise freshwater allocation. Wires Water, 1, 31-40. https://doi.org/10.1002/wat2.1000

Holt-Giménez, E., Shattuck, A., Altieri, M., Herren, H., \& Gliessman, S. (2012). We Already Grow Enough Food for 10 Billion People ... and Still Can't End Hunger. Journal of Sustainable Agriculture, 36(6), 595-598. https://doi.org/10.1080/10440046.2012.695331
Hosny, F. A. (2006). Poultry sector country review, Egypt. Food and Agriculture Organization of the United Nations (FAO).

IFAD. (2019). Investing in rural people in Egypt. Retrieved July 5, 2021 from https://www.ifad.org/documents/38714170/40865296/ Investing+in+rural+people+in+Egypt/24dc8bdb-2d70-48029771-f52122fb3c40

IFAD. (2020). Food systems - transforming food systems for all. Retrieved July 5, 2021 from https://www.ifad.org/en/food-systems.

IFPRI. (2016). Food systems and diets: Facing the challenges of the 21 st century. Global Panel on Agriculture and Food Systems for Nutrition.

Index Mundi. (2021a). Egypt Wheat Domestic Consumption by Year. Retrieved July 5, 2021 from https://www.indexmundi. com/agriculture $/$ ? country $=$ eg $\&$ commodity $=$ wheat $\&$ graph $=$ domestic-consumption

Index Mundi. (2021b). Egypt Chicken Meat Domestic Consumption by Year. Retrieved July 5, 2021 from https://www.indexmundi.com/ agriculture/?country $=$ eg $\&$ commodity $=$ chicken-meat $\&$ graph $=$ domestic-consumption

Kassim, Y., Mahmoud, M., Kurdi, S., \& Breisinger, C. (2018). An agricultural policy review of Egypt: First steps towards a new strategy. International Food Policy Research Institute (IFPRI).

Kandagatla, R., \& Almas, L. K. (2020). Egypt's Reliance on Imported Wheat: Concerns, Challenges and Opportunities. Faculty Research Poster Session and Research Fair, West Texas University. Retrieved July 5, 2021 from https://wtamu-ir.tdl.org/handle/ $11310 / 295$

Mabrouk, M., Jonoski, A., Oude Essink, G. H. P., \& Uhlenbrook, S. (2018). Impacts of sea level rise and groundwater extraction scenarios on fresh groundwater resources in the Nile Delta Governorates, Egypt. Water, 10(11), 1690. https://doi.org/10.3390/ w10111690

McGill, J., Prikhodko, D., Sterk, B., \& Talks, P. (2015). Egypt: Wheat sector review. FAO Investment Centre. Country Highlights Report No. 23. Food and Agriculture Organization of the United Nations (FAO).

Mekonnen, M. M., \& Hoekstra, A. Y. (2011). National water Footprint accounts: the green, blue and grey water Footprint of production and consumption. Value of Water Research Report Series No 50. UNESCO-IHE Institute for Water Education.

Metz, Helen Chapin, ed. (1990) Egypt: A Country Study. Washington: GPO for the Library of Congress, 1990. Retrieved March 14, 2021, from http://countrystudies.us/egypt/84.htm.

Ministry of Agriculture and Land Reclamation (MALR). (2014). Sustainable Agricultural Development Strategy Towards 2030. Arab Republic of Egypt.

Ministry of Agriculture and Land Reclamation of Egypt. (2018). Government to set plan to achieve food security, raise wheat storage. Retrieved March 14, 2021 from https://www.egypttoday.com/Article/1/57088/ Government-to-set-plan-to-achieve-food-security-raise-wheat

Mirzaie-Nodoushan, F., Morid, S., \& Dehghanisanij, H. (2020). Reducing water footprints through healthy and reasonable changes in diet and imported products. Sustainable Production and Consumption, 23, 30-41. https://doi.org/10.1016/j.spc.2020.04.002

Mourad, R., Jaafar, H. H., \& Daghir, N. (2019). New estimates of water footprint for animal products in fifteen countries of the Middle East and North Africa (2010-2016). Water Resources and Industry, 22, 100113. https://doi.org/10.1016/j.wri.2019.100113

Omar, M. E. M., \& Moussa, A. (2016). Water management in Egypt for facing the future challenges. Journal of Advanced Research, 7(3), 403-412. https://doi.org/10.1016/j.jare.2016.02.005

Omar, M. E. M., Moussa, A. M. A., \& Hinkelmann, R. (2021). Impacts of climate change on water quantity, water salinity, food security, and socioeconomy in Egypt. Water Science and Engineering, 14(1), 17-27. https://doi.org/10.1016/j.wse.2020.08.001

Ouda, S., Noreldin, T., \& Abd El-Latif, K. (2015). Water requirements for wheat and maize under climate change in North Nile Delta. 
Spanish Journal of Agricultural Research, 13(1), 1-7. https://doi. org/10.5424/sjar/2015131-6412

Ouda, S. A. H., \& Zohry, A. E. H. (2017). Crops intensification to reduce wheat gap in Egypt. In S. A. H. Ouda, A. E. H. Zohry, H. Alkitkat, M. Morsy, T. Sayad, \& A. Kamel (Eds.), Future of Food Gaps in Egypt, Obstacles and Opportunities (pp. 37-56). Springer. https://doi.org/10.1007/978-3-319-46942-3_4

Oweis, T. (2018). Water management for sustainable agriculture. Burleigh Dodds Science Publishing Limited.

Ramadan, R., \& Thomas, A. (2011). Evaluating the impact of reforming the food subsidy program in Egypt: A Mixed Demand approach. Food Policy, 36(5), 638-646. https://doi.org/10.1016/j. foodpol.2011.06.006

Ramadan, R., \& Hosni, R. (2018). Food subsidy or cash transfer: Impact of the food subsidy reform on Egyptian households. New Medit: A Mediterranean Journal of Economics, Agriculture and Environment, 2018(3). https://doi.org/10.30682/nm1803b

Schyns, J. F., Hamaideh, A., Hoekstra, A. Y., Mekonnen, M. M., \& Schyns, M. (2015). Mitigating the risk of extreme water scarcity and dependency: The case of Jordan. Water, 7(10), 5705-5730. https://doi.org/10.3390/w7105705

Schyns, J. F., \& Hoekstra, A. Y. (2014). The added value of water footprint assessment for national water policy: A case study for Morocco. PLoS ONE, 9(6), e99705. https://doi.org/10.1371/journal.pone.0099705

Soffiantini, G. (2020). Food insecurity and political instability during the Arab Spring. Global Food Security, 26, 100400. https://doi. org/10.1016/j.gfs.2020.100400

Statista. (2021a). Prevalence of obesity in the adult population aged 18 years and older in Egypt from 2007 to 2016. Retrieved July 6, 2021 from https://www.statista.com/statistics/979509/egyptprevalence-of-obesity-adult-population-aged-18-years-and-older/

Statista. (2021b). Egypt: Urbanization from 2010 to 2020. Retrieved March 14, 2021 from https://www.statista.com/statistics/455821/ urbanization-in-egypt/

Talaat, W. (2018). The targeting effectiveness of Egypt's Food Subsidy Programme: Reaching the poor? International Social Security Review, 71(2), 103-123. https://doi.org/10.1111/issr.12168

Ter Maat, H. W., \& Wolters, W. (2016). Definition of climate change scenarios for Egypt and the west delta. Enhanced Water Resources Management Project - Egypt, Technical Study 2. Ministry of Water Resources and Irrigation / World Bank - GEF.

Tompa, O., Lakner, Z., Oláh, J., Popp, J., \& Kiss, A. (2020). Is the Sustainable Choice a Healthy Choice?-Water Footprint Consequence of Changing Dietary Patterns. Nutrients, 12(9), 2578. https://doi.org/10.3390/nu12092578

UNFPA. (2010). Malnutrition. Egypt Demographic and Health Survey 2008, Nutritional Status of the Egyptian Population in Egypt 2010. Retrieved July 6, 2021, from https://egypt.unfpa.org/sites/ default/files/pub-pdf/8d5e9b54-d00e-4d68-8af9-651f5c2734f8. pdf

UNICEF. (2020). Nutrition. Retrieved July 6, 2021, from https://www. unicef.org/egypt/nutrition

UNICEF. (2021). Water, Sanitation and Hygiene. Retrieved July 6, 2021 from https://www.unicef.org/egypt/water-sanitation-andhygiene

Van Berkum, S., Dengerink, J., \& Ruben, R. (2018). The food systems approach: sustainable solutions for a sufficient supply of healthy food. Wageningen Economic Research.

Van den Broek, W. H. A. M., \& Boerrigter, H. A. M. (2014). Metropolitan food supply: case study Cairo: a quick scan study to enhance fresh food supply and minimize postharvest losses. Wageningen UR Food and Biobased Research.

Vanham, D., Comero, S., Gawlik, B. M., \& Bidoglio, G. (2018). The water footprint of different diets within European sub-national geographical entities. Nature Sustainability, 1(9), 518-525. https://doi.org/10.1038/s41893-018-0133-x
Verme, P., Milanovic, B., Al-Shawarby, S., El Tawila, S., Gadallah, M., \& El-Majeed, E. A. A. (2014). Inside Inequality in the Arab Republic of Egypt - Facts and Perceptions across People, Time and Space. The World Bank. https://doi.org/10.1596/978-1-4648-0198-3

Wahba, S. M. (2021). Understanding internal water footprint inequality of the Egyptian households based on different income and lifestyles. Journal of Cleaner Production, 288, 125112. https:// doi.org/10.1016/j.jclepro.2020.125112

Wahba, S. M., Scott, K., \& Steinberger, J. K. (2018). Analyzing Egypt's water footprint based on trade balance and expenditure inequality. Journal of Cleaner Production, 198, 1526-1535. https://doi.org/ 10.1016/j.jclepro.2018.06.266

Wichelns, D. (2001). The role of 'virtual water' in efforts to achieve food security and other national goals with an example from Egypt. Agricultural Water Management, 49(2), 131-151. https:// doi.org/10.1016/S0378-3774(00)00134-7

World Bank. (2020). Poverty and Equality Brief Middle East and North Africa, Arab Republic of Egypt. Retrieved June 9, 2021, from https://databank.worldbank.org/data/download/poverty/33EF03BB9722-4AE2-ABC7-AA2972D68AFE/Global_POVEQ_EGY.pdf

World Bank. (2021). GDP per capita (current US\$) - Egypt, Arab Rep. Retrieved March 14, 2021, from https://data.worldbank.org/indicator/ NY.GDP.PCAP.CD?locations $=$ EG

WorldOMeter. (2021). Egypt Demographics. Retrieved March 14, 2021, from https://www.worldometers.info/demographics/egyptdemographics/

World Trade Organization. (2020). Egypt and the WTO. Retrieved October 20, 2020, from https://www.wto.org/english/thewto_e/ countries_e/egypt_e.htm

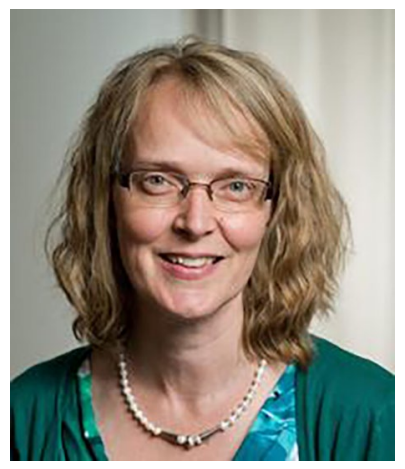

Catharien Terwisscha van Scheltinga is an expert on water management in deltas working at Wageningen Environmental Research, part of Wageningen University and Research. She has over 25 years of experience working on interdisciplinary research linking water management, climate change adaptation and food security. She has a keen interest to work on capacity development, represents Wageningen in the Delta Alliance, an international knowledge network on deltas, and is chair of the Network

Land and Water, a Dutch organization of land and water management professionals.I

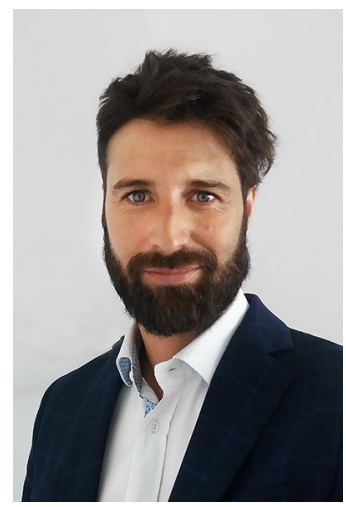

Dr Angel de Miguel is hydrologist at Wageningen Environment Research (WEnR), part of Wageningen University \& Research. His work focuses on the application of an integrated water and land management approach and the evaluation of the water footprint for the agriculture context. He is also involved in the promotion of safe water reuse, primarily intended for irrigation and in the application of nature based solutions for decentralized wastewater treatment (vegetation filters). 


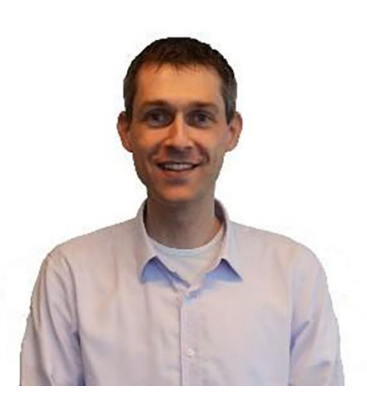

Dr Gert-Jan Wilbers is a water and environmental economics scientist at Wageningen Environment Research (WEnR), part of Wageningen University \& Research. He currently works on water and food related projects to support evidence-based policies in the broad field of environmental and agriculture. He is leading several projects on water, energy, food nexus analyses and financial-economic studies with respect to water and agricultural interventions with a specific focus on the MENA region.

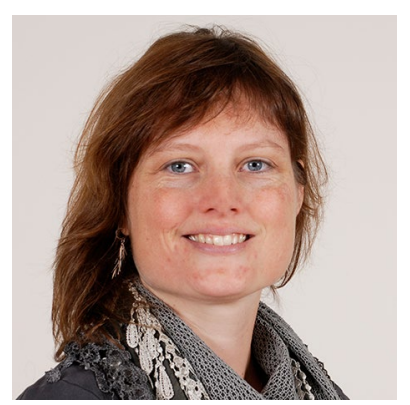

Hanneke Heesmans As a soil fertility researcher for Wageningen Environmental Research, Hanneke Heesmans works in food security projects in Africa and Asia. She currently works on impact of projects, through analyses of data collected, of climate change related to carbon sequestration and integrated soil fertility management.

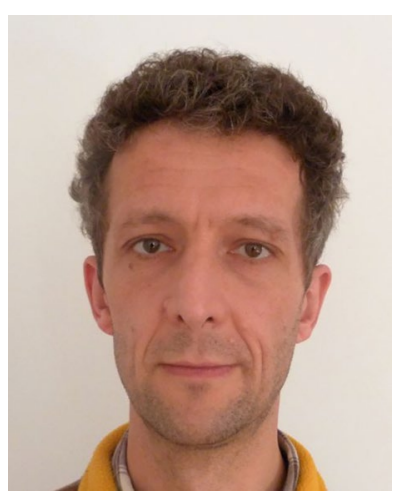

Dr Rutger Dankers is an expert on climate impact assessments at Wageningen Environmental Research, focusing on the impacts of climate change and extreme weather events on natural and socio-economic systems.

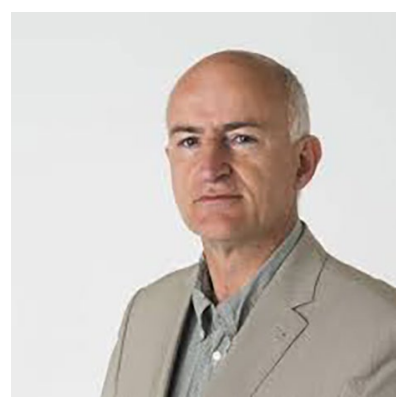

Dr Eric Smaling is a senior researcher of Wageningen Environmental Research at Wageningen University \& Research. He holds an MSc in soil science and a $\mathrm{PhD}$ on soil fertility management from Wageningen University. Smaling conducted research in soil geography, land evaluation and integrated soil fertility management, mainly in Indonesia, East and West Africa. Between 1997 and 2012, he has been Professor of soil science and sustainable agriculture, first at Wageningen University, later at the University of Twente, Faculty of GeoInformation Science and Earth Observation (ITC). Smaling also worked as free-lance consultant to the World Bank, the Food and Agricultural Organization (FAO), The UN Fund for Environmental Protection (UNEP), Rockefeller Foundation, Bill \& Melinda Gates Foundation, and the CGIAR. He has also been a Senator (2007-2013) and then a Member of Lower House (2013-2017) in the Dutch parliament for the Socialist Party. Since 2017 he joined Wageningen University \& Research again to provide guidance to several large international programs for rural and agricultural development. 